\title{
Postharvest conservation of 'Tommy Atkins' mango with bio-organic coating of Chlorella sp.
}

\author{
Conservação pós-colheita de manga 'Tommy Atkins' com recobrimento \\ bio-orgânico de Chlorella sp.
}

\begin{abstract}
Ágda Malany Forte de OLIVEIRA ${ }^{1}$; Railene Hérica Carlos ROCHA²; Wellinghton Alves GUEDES ${ }^{3}$; Tádria Cristiane de Sousa FURTUNATO4; José Franciraldo de LIMA ${ }^{5}$

${ }^{1}$ Autor para correspondência. Estudante de Agronomia, Universidade Federal de Campina Grande - Centro de Ciência e Tecnologia Agroalimentar (UFCG/CCTA).E-mail: agdamalany@hotmail.com

2 Eng. Agronôma, Dra. em Fitotecnia. Professora/pesquisadora da Universidade Federal de Campina Grande - Centro de Ciência e Tecnologia Agroalimentar (UFCG/CCTA). E-mail: raileneherica@ccta.ufcg.edu.br

${ }^{3}$ Eng. Agrônomo, estudante de pós-graduação (Mestrado em Horticultura tropical) Universidade Federal de Campina Grande - Centro de Ciência e Tecnologia Agroalimentar (UFCG/CCTA). Email: wellinghton_guedes@hotmail.com

${ }^{4}$ Eng. Agronôma, Mestre em Horticultura Tropical - Universidade Federal de Campina Grande - Centro de Ciência e Tecnologia Agroalimentar (UFCG/CCTA). E-mail: tadriacsf@hotmail.com

${ }^{5}$ Biotecnólogo, Universidade de São Paulo (USP). Instituto Fazenda Tamanduá. Caixa Posta 65, CEP:58700-970, Patos, PB. E-mail: josefranciraldo@gmail.com
\end{abstract}

Recebido em: 27-03-2017; Aceito em: 15-08-2017

\begin{abstract}
The objective of the present work was to evaluate the effect of microalgae-based coatings in the postharvest conservation of 'Tommy Atkins' mango, subjected to storage under refrigerated conditions and under ambient conditions. Two experiments were carried out, one under refrigeration (Experiment I), with 21 days at $10^{\circ} \mathrm{C}$ and $42 \%$ $\mathrm{RH}$ and then seven days at $25{ }^{\circ} \mathrm{C}$ and $42 \% \mathrm{RH}$, and another at room temperature, at $23{ }^{\circ} \mathrm{C}$ and $42 \% \mathrm{RH}$ (Experiment II) for ten days. Both experiments were set up in a completely randomized design, whose treatments consisted of the doses of $0 \%, 1 \%, 2 \%, 3 \%$ and $4 \%$ Chlorella sp. An increase above $2 \%$ in the contraction of Chlorella sp. causes delay in ripening. The best physicochemical indications for maintenance of 'Tommy Atkins' mango quality were observed in fruits that received the coating of $1 \%$ Chlorella sp., reflecting good appearance, fresh mass loss of less than $5.5 \%$ and total sugars above $12 \%$, under both storage conditions.
\end{abstract}

Additional keywords: biofilm; Mangifera indica L.; microalga; postharvest.

\section{Resumo}

O objetivo do presente trabalho foi avaliar o efeito de revestimentos à base de microalga sob a conservação póscolheita de manga 'Tommy Atkins', submetida ao armazenamento sob condições de refrigeração e sob condições ambiente. Instalaram-se dois experimentos, um sob refrigeração a $10 \stackrel{\circ}{ } \mathrm{C}$ (Experimento I), sendo 21 dias a $10{ }^{\circ} \mathrm{C}$ e $42 \%$ UR e, em seguida, sete dias a $25{ }^{\circ} \mathrm{C}$ e $42 \%$ UR, e outro sob temperatura ambiente a $23 \stackrel{\circ}{\circ}$ e $42 \%$ UR (Experimento II), por dez dias. Ambos os experimentos foram instalados em delineamento inteiramente ao acaso, cujos tratamentos foram constituídos pelas doses de $0 \%, 1 \%, 2 \%, 3 \%$ e $4 \%$ de Chlorella sp. O aumento na contração de Chlorella sp., acima de $2 \%$, provoca retardamento no amadurecimento. Os melhores indicativos físico-químcos de manutenção da qualidade da manga 'Tommy Atkins' foram observados nos frutos que receberam o recobrimento a $1 \%$ de Chlorella sp., como reflexo na boa aparência, na perda de massa fresca inferior a $5,5 \%$ e em açúcares totais acima de $12 \%$, em ambas as condições de armazenamento.

Palavras-chave adicionais: biofilme; Mangifera indica L.; microalga; pós-colheita.

\section{Introduction}

Brazil ranks third in the world ranking of fruit producers, behind only China and India. Among the 25 fruit species that Brazil exports, mango (Mangifera indica L.) has a prominent position, positioning the country as the $7^{\text {th }}$ largest fruit exporter in the world (FAO, 2013; Santos, 2014). Production is mostly absorbed by the domestic market and around $10 \%$ of the production is exported. In 2015, the highest revenue, of US\$184.342 million, was obtained with the shipment of 156.337 thousand tons of mango. The result was $17.52 \%$ higher in tons and $12.59 \%$ higher in value in relation to 2014 (Treichel et al., 2016).

For Brazil to consolidate its position as the main exporter of mango to Europe, increase its participation in the American market and reach the newly opened Asian market, it is necessary to use the sea route. For Trindade et al. (2015), the maritime transport stage stands out as critical for the occurrence of losses, due to the long period and the storage conditions. However, air transportation would be the best 
option for the external market, but the high cost limits its use. According to Rocha et al. (2016), the postharvest shelf life of mango is limited due to deterioration, dehydration and development of pathogens, thus damaging the commercial value.

Refrigeration is an important alternative to prolong the postharvest shelf life of the fruits, it enables long-distance commercialization, reduction of losses during transportation and allows the product to reach the consumer in optimum conditions, notwithstanding, it makes transportation more expensive.

In addition to refrigeration, other technologies can be implemented to delay the ripening of mangoes. For example, the use of ethylene inhibitors may delay dehydration and maintain their appearance (Fakhouri et al., 2007). The use of biofilms can be a useful alternative for postharvest conservation of fruits, besides being able to reduce costs with refrigeration, reduce environmental pollution and promote consumer food safety.

Chlorella sp. is composed of about $42-58 \%$ of its dry biomass mass, in addition to synthesizing essential and non-essential amino acids, which corroborates favorably the human nutrition standard proposed by the World Health Organization (WHO) and the Food and Agriculture Organization (FAO). Its biomass consists of $40 \%$ lipids, also presenting starch and cellulose. One of the main polysaccharides present is $\beta 1 \rightarrow 3$ glucan, which provides several health benefits, being rich in pigments such as chlorophyll and beta-carotene (Lordan et al. 2011; Safi et al., 2013).

Some research using microalgae-based biofilms for fruit coatings are being developed, demonstrating potential for postharvest conservation. According to Onias et al. (2016), mango coating using Spirulina platensis acts as a barrier against external elements, protecting the product and increasing its shelf life without risks to consumer health. Moreira \& Rocha (2015) used the coating based on Spirulina platensis in pomegranate and reported positive effects on the maintenance of organic acids in the fruits. According to the authors, the coating with $3 \%$ cassava starch plus 3\% Spirulina platensis, associated with refrigeration at $10{ }^{\circ} \mathrm{C}$ and $56.7 \% \mathrm{RH}$, was prominent in fruit conservation during storage.

In this sense, the objective of the present work was to evaluate the effect of microalgae-based coatings in the postharvest conservation of 'Tommy Atkins' mango, subjected to storage under refrigerated conditions and under ambient conditions.

\section{Material and methods}

The fruits were obtained in an organic mango orchard, in the municipality of Santa Terezinha, PB. The mangoes were harvested manually in the morning at maturation stage II, showing a green-colored peel with red dashes (Protrade, 1992), accompanied by a peduncle. A previous selection was made in the field, avoiding fruits with symptoms of anthracnose, scab and cochineal infestation, burned by the flow of latex and deformed. After harvesting, the fruits were packed in a single layer in containers previously coated with shredded paper to minimize the impact and the friction between them.

Later, they were transported to the Food Analysis Laboratory of the Federal University of Campina Grande, Pombal-PB campus, where again the selection of uniformity of size and color was made, excluding those with defects or injuries due to transport. Subsequently, they were washed with $1 \%$ neutral detergent solution and, after rinsing, sanitized with sodium hypochlorite solution (100 ppm free chlorine) for 15 minutes and then dried in the open air.

The experimental design was the completely randomized (CRD), using for each experiment 5 replicates and 2 fruits per plot. To obtain the proposed concentrations of the coatings, the following proportions $1 \%, 2 \%, 3 \%$ and $4 \%$ of Chlorella sp. biomass diluted in distilled water under constant stirring until complete homogenization of the solution. The treatments were applied to the fruits by means of micro-sprinklers until the pouring point, then the fruits were dried in the open air, being subsequently conditioned, in experiment I, in a B.O.D. chamber at $10 \stackrel{\circ}{ } \mathrm{C}$ and $42 \% \mathrm{RH}$ for 21 days, remaining thereafter for seven days at $25^{\circ} \mathrm{C}$ and $42 \%$ $\mathrm{RH}$ in an air-conditioned room, being analyzed at 28 days of storage. In experiment II, the fruits were conditioned in an air-conditioned room at $23 \stackrel{\circ}{\circ} \mathrm{C}$ and $42 \% \mathrm{RH}$ for ten days and then analyzed.

The color of the peel and pulp was analyzed by reflectometry using a Konica Minolta colorimeter, model Chroma meter CR-400, color space $L^{*}, a^{*}, b^{*}$. Calibration was performed with a standard white plate, following the manufacturer's instructions. The color parameters measured with respect to the standard plate were: from the $L^{*}, a^{*}, b^{*}$ values, the hue angle, $\mathrm{H}^{\circ}\left(\mathrm{H}^{\circ}=\operatorname{arctang}\left(\mathrm{a}^{*} / \mathrm{b}^{*}\right)(-1)+90\right)$, was calculated for negative ${ }^{*} a$, and $\mathrm{H}^{\circ}=90-\operatorname{arctang}\left(\mathrm{a}^{*} / \mathrm{b}^{*}\right)$ for positive ${ }^{*} \mathrm{a}$, in addition to the chroma saturation index, $\mathrm{C}^{*}$ $\left(C^{*}=\left[\left(a^{*}\right)^{2}+\left(b^{*}\right)^{2}\right]^{1 / 2}\right)$ (Pinheiro, 2009); color of the peel and pulp, visual method: color scale was used (Protrade, 1992). For the pulp, the following scale was used: 1 - Green fruit; 2 - Green with yellow dashes; 3 - More green than yellow; 4 - More yellow than green; and 5 - Green dashes. For the peel color, the same scale was used, varying from green to red; fresh mass loss: the fruits were weighed in an electronic scale, on the day of the installation of the experiments and at the end of the packaging. The results were expressed as a percentage, considering the difference between the initial mass of the fruit and that obtained at the end of storage.

The homogenized pulp used in the evaluations was obtained after fruit peeling and processing in a domestic centrifuge. The following variables were then analyzed: a) Titratable acidity (TA), by titration of $1 \mathrm{~mL}$ of mango juice diluted to $50 \mathrm{~mL}$ of distilled water, under constant stirring, with sodium hydroxide solution $(0.1 \mathrm{M}$ 
$\mathrm{NaOH})$, according to IAL (2008); b) Soluble solids (SS), determined in the juice by means of a direct reading in a brand digital refractometer Instrutherm (AOAC, 2006); c) SS/TA ratio, calculated by the quotient between the two variables; d) Vitamin $C$, determined by titration of $1 \mathrm{~mL}$ of mango juice diluted to $49 \mathrm{~mL}$ of oxalic acid, under constant stirring, with DFI solution, according to Tillman's method (AOAC, 2006); and e) Total sugars, determined by the anthrone method, according to the procedure described by Yemn \& Willis (1954) with modifications. Two dilutions were made. First, $1 \mathrm{~g} \mathrm{~mL}^{-1}$ of the sample was diluted to $100 \mathrm{~mL}$ of distilled water, then $0.01 \mathrm{~g} \mathrm{~mL}^{-1}$ of the first dilution was added with $50 \mathrm{~mL}$ of distilled water. From this second dilution, $1 \mathrm{~mL}$ was used, to which $2 \mathrm{~mL}$ of anthrone was added in a stirred tube, being placed in a water bath at $100^{\circ} \mathrm{C}$ for 5 minutes. After cooling, the samples were taken to the spectrophotometer for reading.

The results were submitted to analysis of variance and polynomial regression from the means obtained from the samples of each treatment, compared by the significance of the $R^{2}$ value and the
Student's t-test at $5 \%$ of probability, using the software SISVAR version 5.3 (Ferreira, 2011).

\section{Results and discussion}

\section{Experiment I}

According to the analysis of variance, the peel color evaluated by the grade scale had a significant effect at the $5 \%$ probability level. The peel color had linear effect (Figure 1A), whose $0 \%$ (control) dose had a mean score of 4.23 and the doses of 2 and $4 \%$ obtained mean scores of 3.23 and 3.26, more green than red, respectively, indicative of maturation delay at 28 days of storage.

Figure $1 \mathrm{~B}$ shows that the pulp color index showed no significant effect at the $5 \%$ level and no regression adjustment for the doses of Chlorella sp. after 28 days of storage. The fruits that were submitted to the dose of $2 \%$ presented a color more green than yellow, collaborating with what was observed in the peel color at the respective dose.
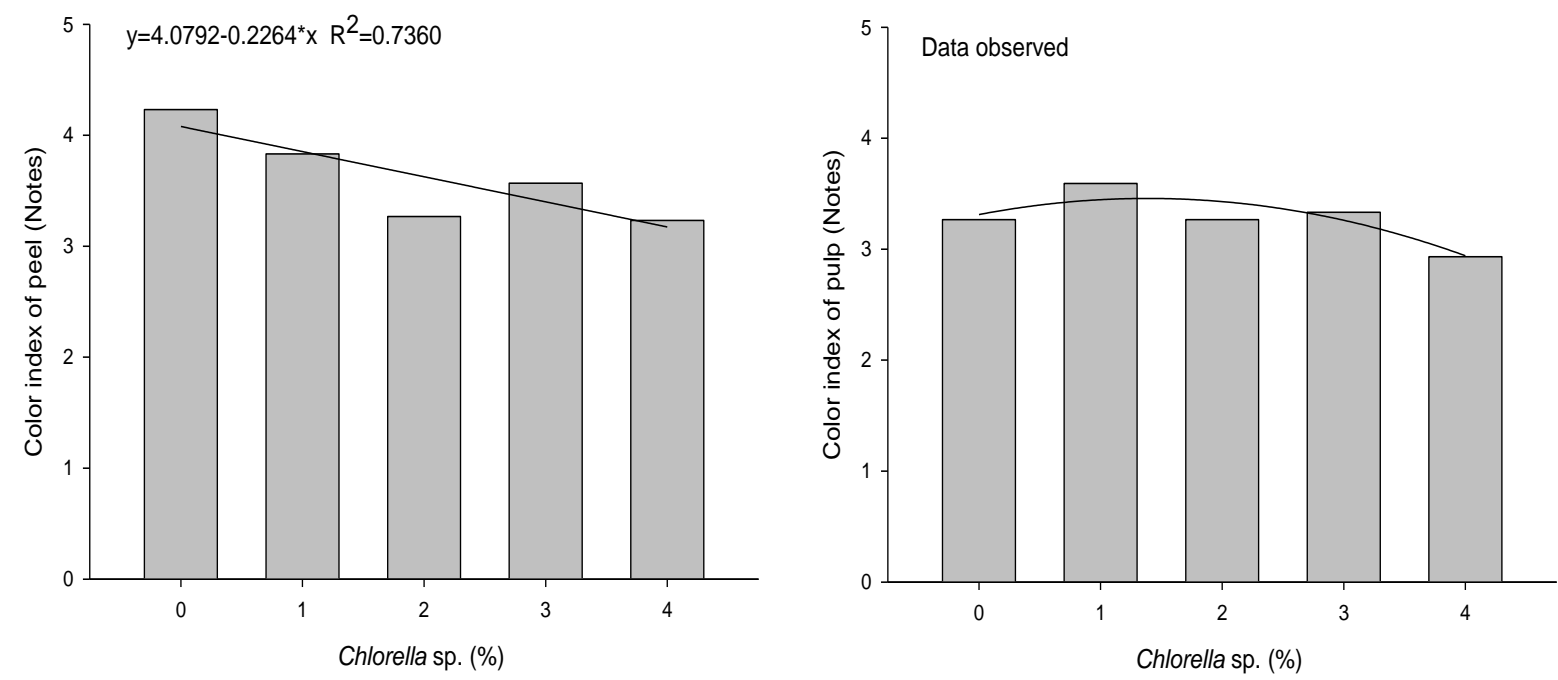

Figure 1 - Color index of peel (A) and pulp (B) mango cv. Tommy Atkins treated with Chlorella sp. after 28 days of storage ( 21 days at $10{ }^{\circ} \mathrm{C}$ and $42 \% \mathrm{RH}$ and then seven days at $25^{\circ} \mathrm{C}$ and $42 \% \mathrm{RH}$ ).

The results of the hue angle of the peel and pulp are presented in Figure 2. The $\mathrm{H}^{\circ}$ of the peel and pulp did not fit the regression, with the highest value of peel $\mathrm{H}^{\circ}$ being observed in the dose of $2 \%$ Chlorella sp. (75.05), indicating that the peel was in transition to red color (Figure 2A). In the pulp, the color angle showed little variation between the treatments, with a mean of 87.20 representing a light-yellow pulp color (Figure 2B).

The peel chromaticity $\left(C^{*}\right)$ had a linear decreasing behavior with increasing doses of Chlorella $\mathrm{sp}$., thus with a reduction in color saturation. When applying the dose of $4 \%$ Chlorella sp., the fruits reached the lowest value (26.89), revealing a change in the color of the 'Tommy Atkins' mango fruits treated with different doses of Chlorella sp. after 28 days of storage (Figure 3A). Amariz et al. (2010) observed in mangoes of the same variety, coated with carboxymethylcellulose and dextrin, an increase in the $\mathrm{C}^{*}$ values of the peel, indicating greater intensity of color in the peel of the mangoes. The reduction behavior of the peel $\mathrm{C}^{*}$ may have occurred because of the effectiveness of the coating in delaying chlorophyll degradation.

Regarding the $\mathrm{C}^{*}$ index in the pulp, no regression adjustment was possible (Figure 3B). Values varying from 56.56 to 60.28 were found, with the lowest value (56.04) being observed at the dose of $2 \%$ Chlorella sp. after 28 days of storage. 
A B
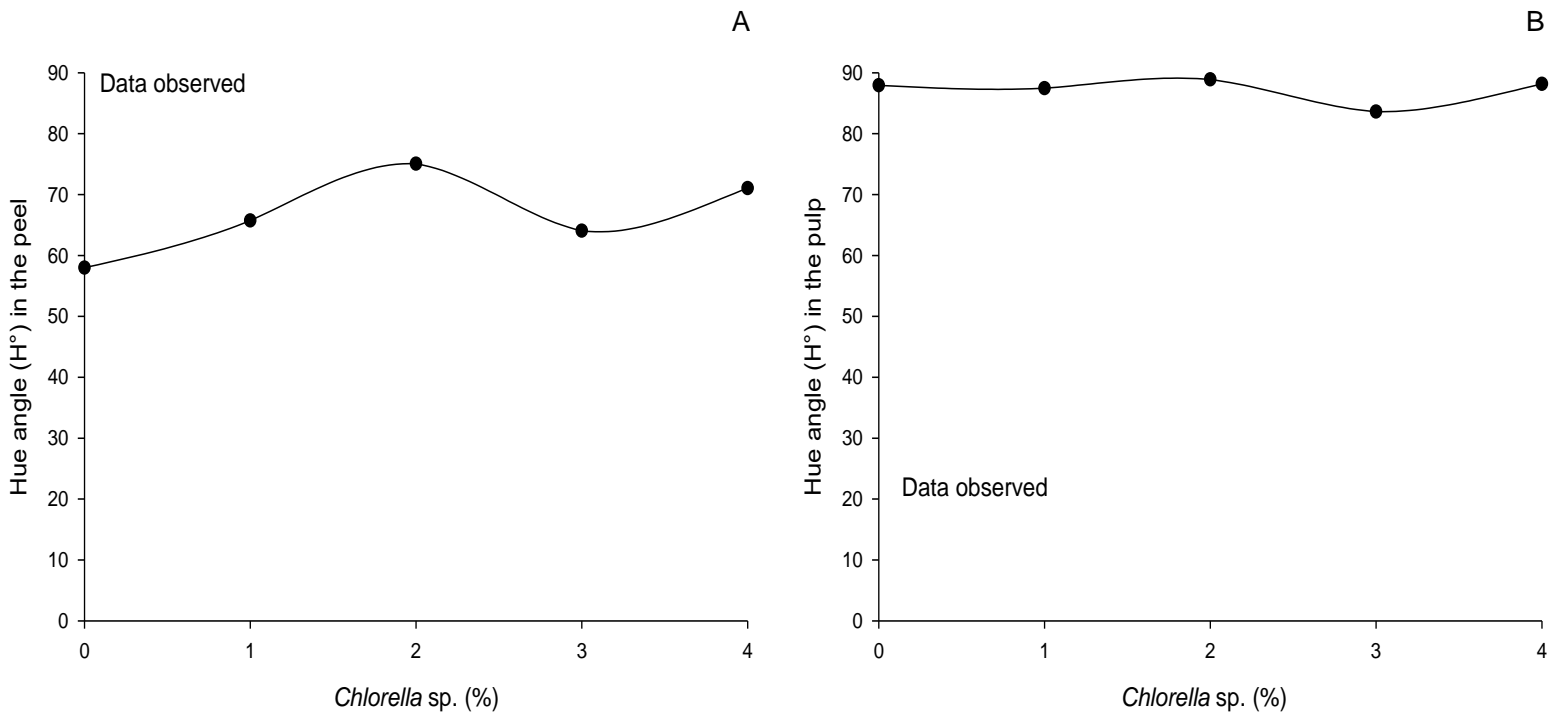

Figure 2 - Hue angle $\left(\mathrm{H}^{\circ}\right)$ in the peel $(\mathrm{A})$ and in the pulp $(\mathrm{B})$ mango cv. Tommy Atkins treated with Chlorella sp. after 28 days of storage ( 21 days at $10^{\circ} \mathrm{C}$ and $42 \% \mathrm{RH}$ and then seven days at $25^{\circ} \mathrm{C}$ and $42 \% \mathrm{RH}$ ).

A
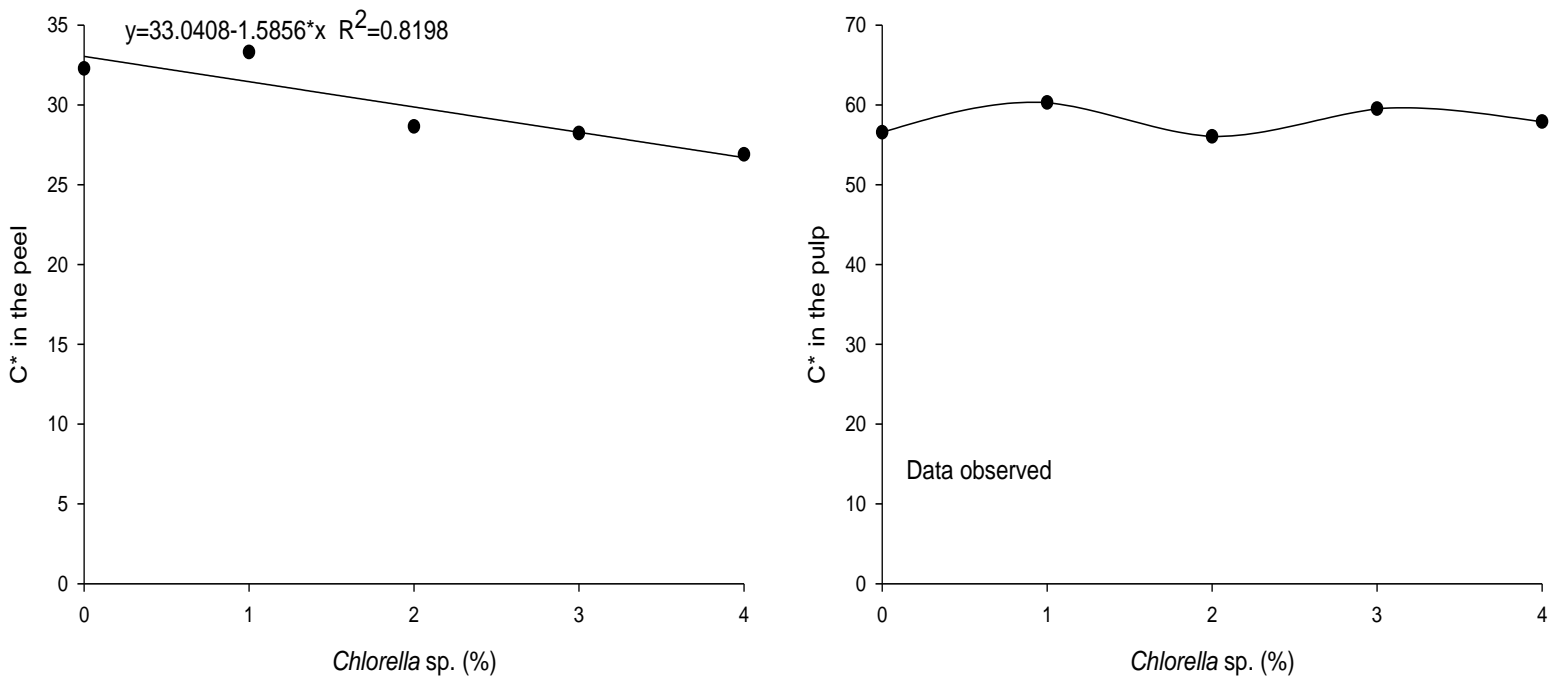

Figure 3 - Chromaticity $\left(\mathrm{C}^{*}\right)$ in the peel $(\mathrm{A})$ and in the pulp $(\mathrm{B})$ mango cv. Tommy Atkins treated with Chlorella sp. after 28 days of storage ( 21 days at $10^{\circ} \mathrm{C}$ and $42 \% \mathrm{RH}$ and then seven days at $25^{\circ} \mathrm{C}$ and $42 \% \mathrm{RH}$ ).

For fresh mass loss, a cubic behavior was observed with values between $4.74 \%$ and $5.36 \%$ (Figure 4$)$. The dose of $3 \%$ Chlorella sp. was responsible for the lowest fresh mass loss after 28 days of storage, presenting a value of $4.74 \%$, indicating that the coating based on Chlorella sp. acted in protecting the fruits from losing water. The doses of $1 \%, 2 \%$ and $4 \%$ Chlorella sp. presented mean values close to the dose of 0 (control). Onias et al. (2016), studying coatings based on cassava starch and maize starch enriched with Spirulina platensis, verified a linear reduction of the mass loss of mangoes cv. 'Tommy Atkins', with the treatment of $3 \%$ cassava starch plus 3\% Spirulina platensis being responsible for less mass loss. This indicates that the use of microalgae-based coatings may be a potential option for fruit coating due to its rich composition in proteins, starch and lipids, and they may act as a semipermeable barrier (Safi et al., 2014).

The values of total sugars found in the pulp of mango cv. 'Tommy Atkins' treated with different doses of Chlorella sp. after 28 days of storage varied slightly

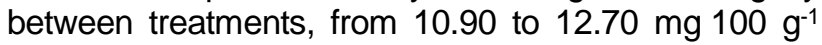
(Figure 5). The behavior of total sugars was not affected by the application of the coatings, indicating that there was no change in the flavor of the fruits coated with Chlorella sp. Amariz et al. (2010) observed an increase in total sugars during storage in mangoes of the same variety coated with carboxymethylcellulose and dextrin, consistent with the fruit ripening process. 


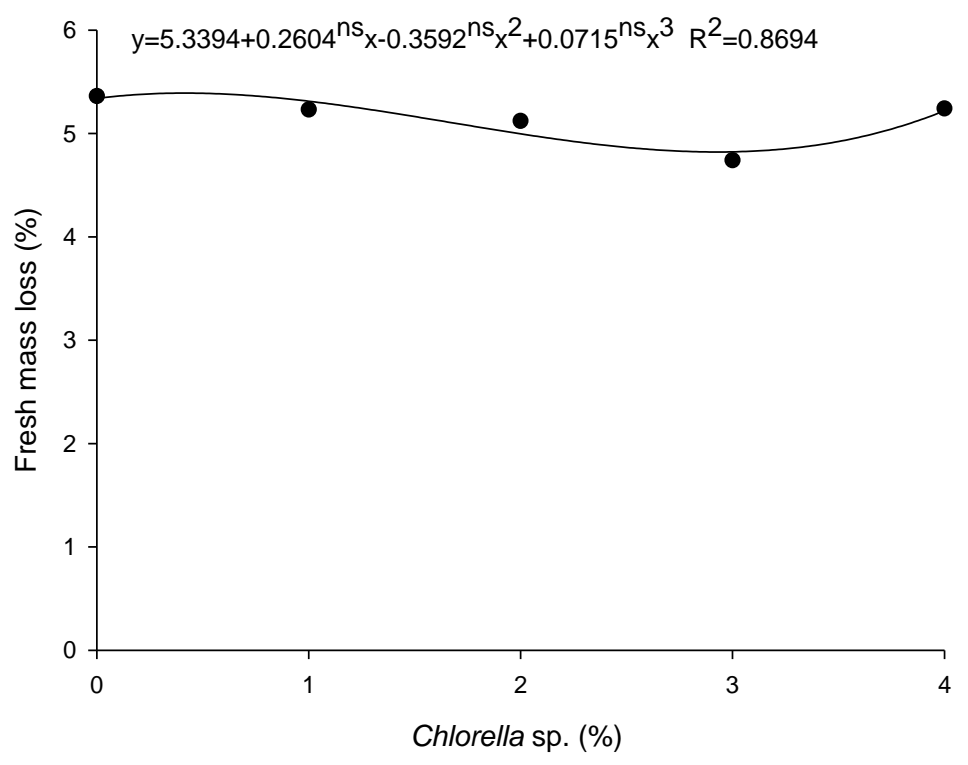

Figure 4 - Loss of mass fresh mango cv. Tommy Atkins treated with Chlorella sp. after 28 days of storage (21 days at $10^{\circ} \mathrm{C}$ and $42 \% \mathrm{RH}$ and then seven days at $25^{\circ} \mathrm{C}$ and $42 \% \mathrm{RH}$ ).

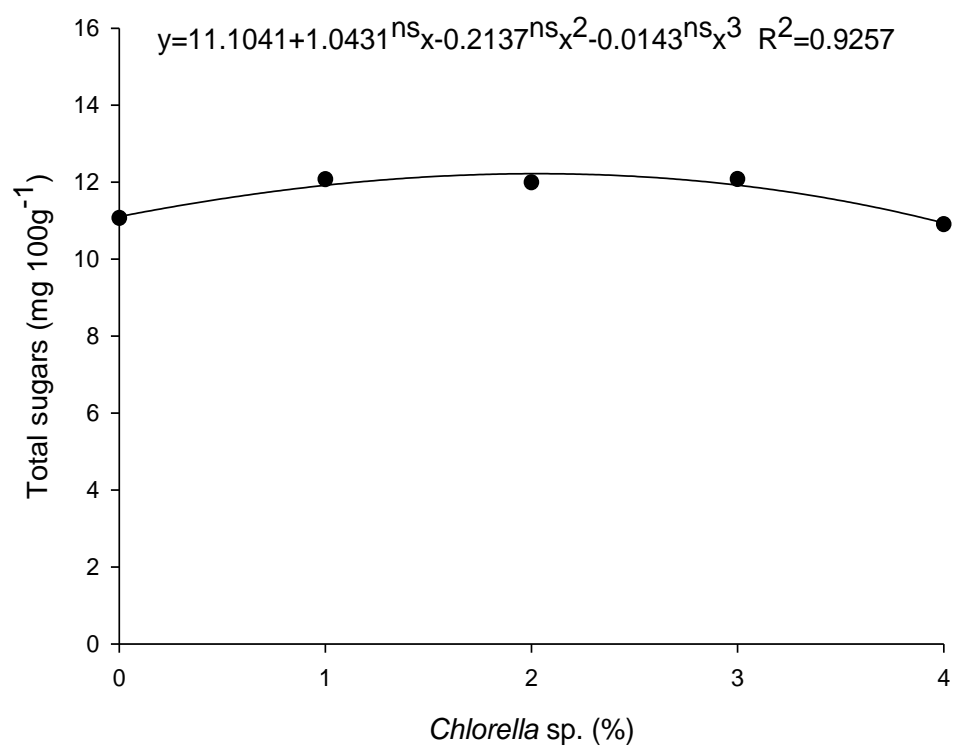

Figure 5 - Total sugars of mango cv. Tommy Atkins treated with Chlorella sp. after 28 days of storage (21 days at $10^{\circ} \mathrm{C}$ and $42 \% \mathrm{RH}$ and then seven days at $25^{\circ} \mathrm{C}$ and $\left.42 \% \mathrm{RH}\right)$.

\section{Experiment II}

According to Figure $6 \mathrm{~A}$, considering the visual method, a reduction in the means of the peel color was observed with increasing doses of Chlorella sp., and the concentration of $4 \%$ presented the lowest mean (2.99), showing fruits still green, indicative that Chlorella sp. delayed maturation. In the pulp (Figure $6 \mathrm{~B})$, there was a varied behavior in the doses of Chlorella sp.; the doses of 3 and $4 \%$ presented a similar effect, 3.76 and 3.66, respectively, that is, the pulp had a color more green than yellow after ten days of storage at $23{ }^{\circ} \mathrm{C}$ and $42 \% \mathrm{RH}$. Vieira et al. (2009) reported the efficiency of the cassava starch-based or maize starch-based coating containing sunflower oil in maintaining the color of the peel and pulp of mangoes of the same variety. This indicates that the use of the coating may have acted as a semipermeable barrier to gas exchange, reducing the respiratory rate and delaying the changes in the pigmentation of the peel and pulp of the fruits. 
A
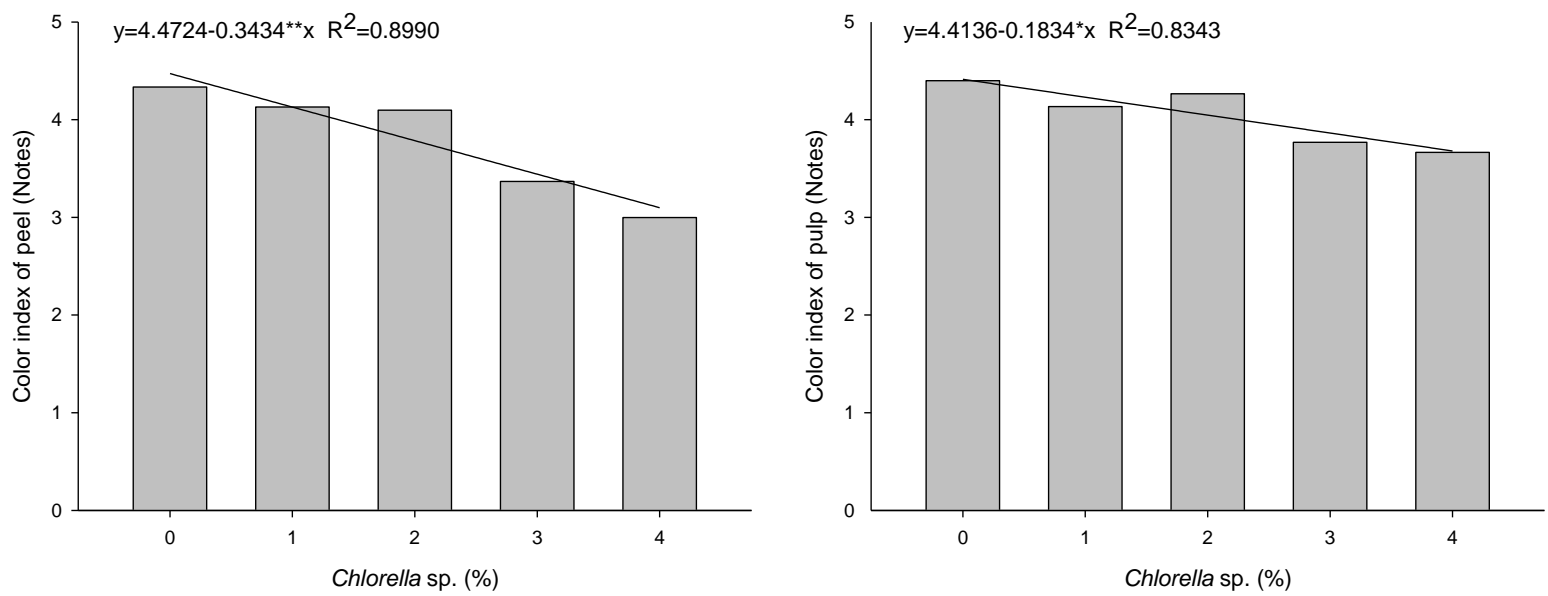

Figure 6 - Color index of peel (A) and pulp (B) mango cv. 'Tommy Atkins' treated with Chlorella sp., after ten days storage $\left(23^{\circ} \mathrm{C}\right.$ and $\left.42 \% \mathrm{RH}\right)$.

The peel $\mathrm{H}^{\circ}$ had an increasing linear behavior as a function of increasing doses of Chlorella, ranging from 60.25 to 86.77 in the concentrations of 1 and $4 \%$, respectively, indicative of the coating's ability to restrain ripening (Figure 7A). Fruits coated with 3 and $4 \%$ Chlorella visually presented peels less red than fruits without coating and coated with $1 \%$ of the coating.

For the pulp, there was little variation in the $\mathrm{H}^{\circ}$ angle values as a function of increasing doses of
Chlorella sp., whose mean in the experiment was 83.14 (Figure 7B). Serpa et al. (2014) reported for the color angle a progressive reduction in 'Palmer' mango pulps during storage, characterizing the mango pulps as orangish yellow on the day of evaluation. Changes in color intensities are associated with fruit metabolism during ripening, so it is believed that Chlorella doses have delayed the degradation process of the pigments that maintain the attractive color of the fruits.

A
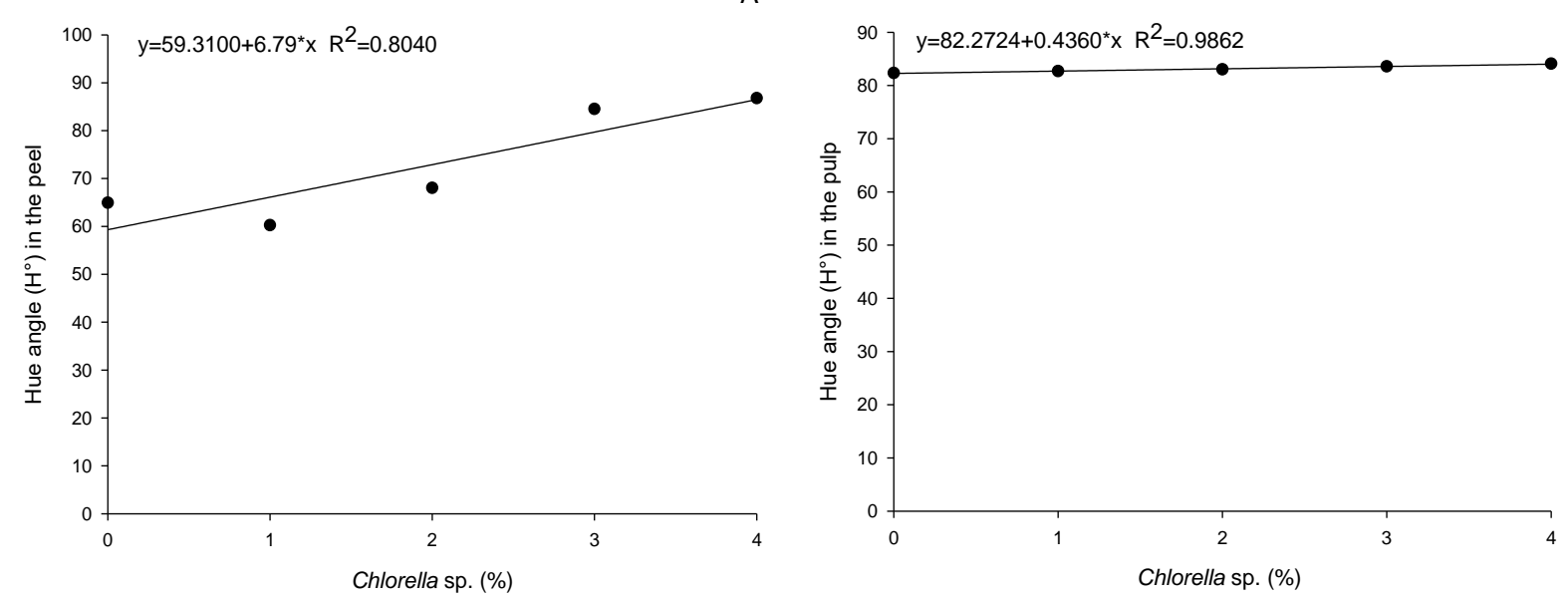

Figure 7 - Hue angle $\left(\mathrm{H}^{\circ}\right)$ in the peel $(\mathrm{A})$ and in the pulp (B) mango cv. 'Tommy Atkins' treated with Chlorella sp., after tendays storage $\left(23^{\circ} \mathrm{C}\right.$ and $\left.42 \% \mathrm{RH}\right)$.

For the $\mathrm{C}^{*}$ index expressing the color saturation, a distinct behavior was observed in the peel and pulp, with linear and cubic behavior, respectively (Figure $8 \mathrm{~A}$ and $\mathrm{B}$ ). It is observed that the saturation of the peel color tends to decrease as the dose of Chlorella $\mathrm{sp}$. increases, probably due to the interference of Chlorella sp., which avoided color alteration, with the dose of $4 \%$ being responsible for the smallest change in color intensity. In the pulp, the $\mathrm{C}^{*}$ presented a differ-

entiated behavior, where the dose of $1 \%$ was responsible for the lowest intensity, while the doses of 2, 3 and $4 \%$ presented similar values (Figure $8 \mathrm{~B}$ ). This chromaticity variation in the fruit parts may be related to the delaying of the ripening process caused by the use of Chlorella sp., which by covering the fruits can decrease the respiratory process and consequently the changes caused by it. 

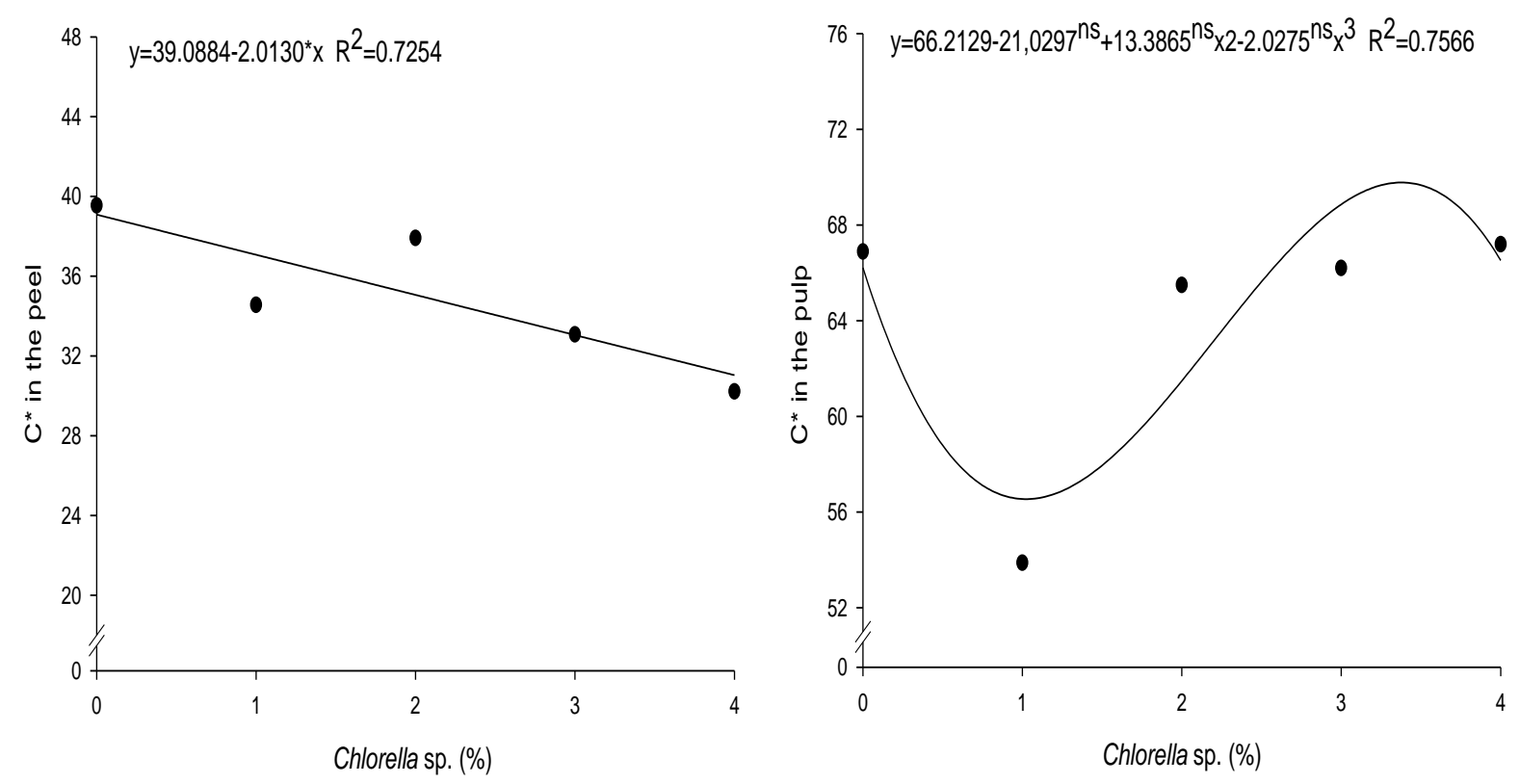

Figure 8 - Chromaticity $\left(\mathrm{C}^{\star}\right)$ in the peel $(\mathrm{A})$ and in the pulp (B) mango cv. 'Tommy Atkins' treated with Chlorella sp., after ten days storage $\left(23^{\circ} \mathrm{C}\right.$ and $\left.42 \% \mathrm{RH}\right)$.

According to Figure 9, there was no regression adjustment for fresh mass loss. It is verified that the concentration of $2 \%$ Chlorella sp. was responsible for the greater fresh mass loss of the fruit, while the doses of 1,3 and $4 \%$ showed similar losses, which reveals that these three doses present greater efficiency in the

control of fresh mass loss when compared to the $2 \%$ dose. The coating of the fruits promotes the partial filling of stomata and lenticels, thus reducing moisture transfer and gas exchange (Luvielmo \& Lamas, 2012), consequently reducing water loss.

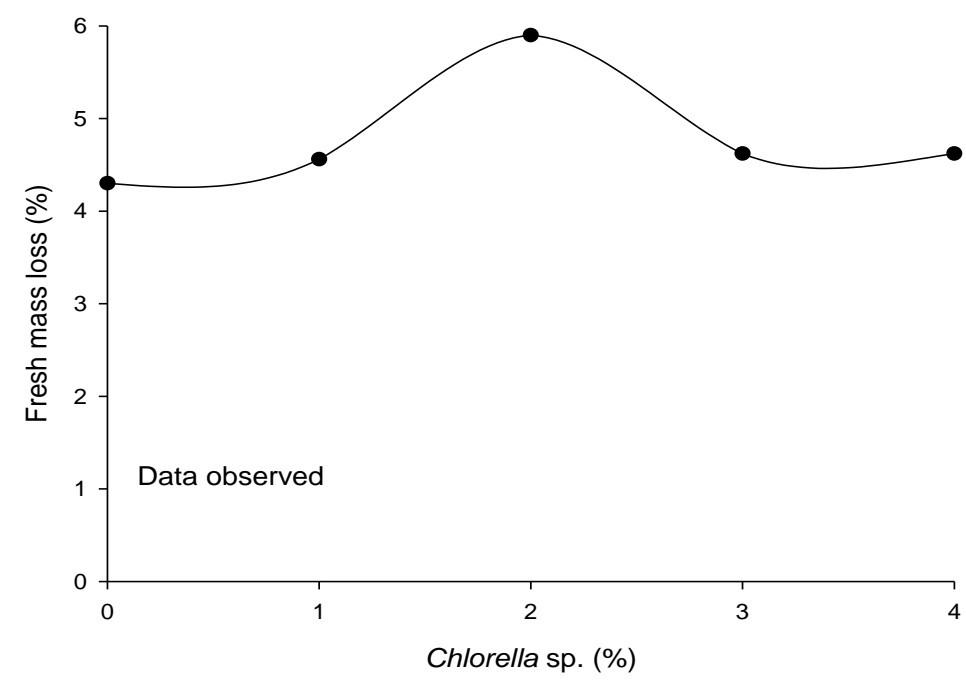

Figure 9 -- Loss of mass fresh mango cv. 'Tommy Atkins' treated with Chlorella sp., after ten days storage (23 $\stackrel{\circ}{\mathrm{C}}$ and $42 \% \mathrm{RH}$ ).

For total sugars, a cubic behavior was observed as a function of increasing doses of Chlorella sp. after ten days of storage at $23^{\circ} \mathrm{C}$ and $42 \% \mathrm{RH}$ (Figure 10). It was verified that the $3 \%$ dose had the lowest total sugar concentration among the doses studied, and the fruits in which the dose of $4 \%$ was applied presented the highest total sugar concentration. 


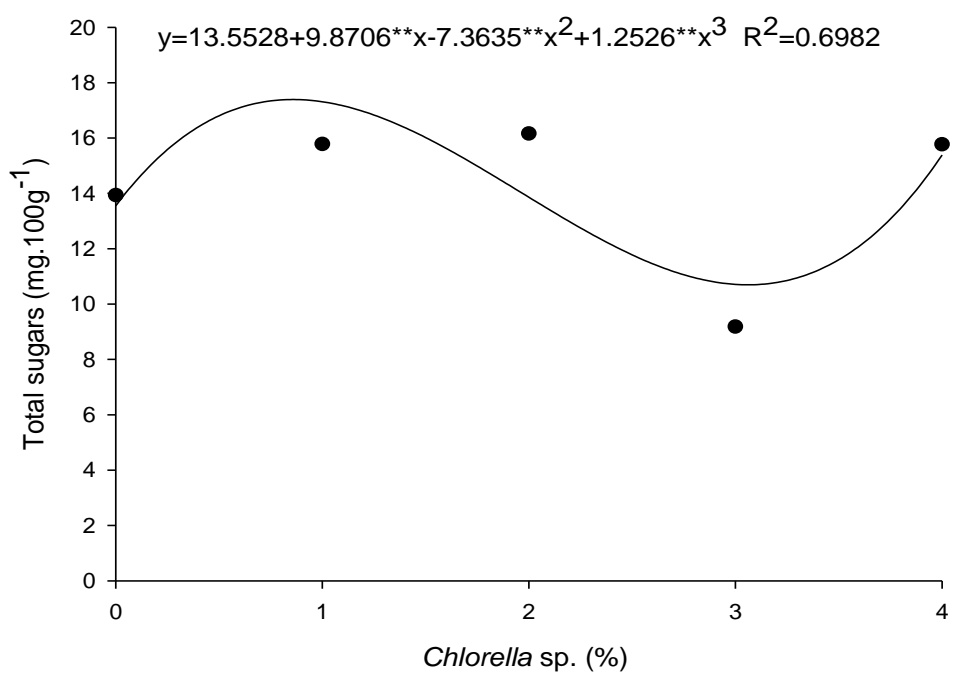

Figure 10 - Total sugars of mango cv. Tommy Atkins' treated with Chlorella sp. After ten days storage $\left(23^{\circ} \mathrm{C}\right.$ and $42 \% \mathrm{RH}$ ).

\section{Conclusions}

The best physicochemical indications for maintenance of 'Tommy Atkins' mango quality were observed in fruits that received the coating of $1 \%$ Chlorella sp., reflecting good appearance, fresh mass loss of less than $5.5 \%$ and total sugars above $12 \%$, under both storage conditions.

\section{References}

Amariz A, Lima MACD, Trindade DCGD, Santos ACND, Ribeiro TP (2010) Recobrimentos à base de carboximetilcelulose e dextrina em mangas 'Tommy Atkins' armazenada sob refrigeração. Ciência Rural 40(10):2199-2205 .

AOAC - Association of Official Analytical Chemists (2006) Official methods of analysis of the Association of official analytical chemists. Gaithersburg: AOAC .18th ed.

Fakhouri FM, Fontes LCB, Gonçalves PVM, Milanez CR, Steel CJ, Collares-Queiroz FP (2007) Filmes e coberturas comestíveis compostas à base de amidos nativos e gelatina na conservação e aceitação sensorial de uvas Crimson. Ciência e Tecnologia de Alimentos 27(2):369-375.

Ferreira DF (2011) SISVAR: A computer statistical analysis system. Ciência e Agrotecnologia 35(6):10391042.

Food and Agriculture Organization-FAO. FAOSTAT. 2013. Disponível em: <http://faostat.fao.org>. Acesso em: 28 dez. 2016.
IAL - Instituto Adolfo Lutz (2008) Normas analíticas do instituto Adolfo Lutz. $4^{\circ}$ Ed. São Paulo: IAL.

Lordan S, Ross RP, Stanton C (2011) Marine bioactives as functional food ingredients: potential to reduce the incidence of chronic diseases. Marine Drugs 9(6):1056-1100.

Luvielmo MM, Lamas SV (2012) Revestimentos comestíveis em frutas. Estudos Tecnológicos em Engenharia 8(1):8-15.

Moreira LS, Rocha RHC (2015) Estudo da qualidade da romã 'Molar': romã 'Molar' submetida a temperaturas de armazenamento e revestimento comestível. Novas Edições Acadêmicas, Alemanha,76p.

Onias EA, Rocha RHC, Lima JF, Onias EA, Furtunato TCS (2016) Organic 'Tommy Atkins' mango postharvest quality when treated with biofilms enriched by Spirulina platensis.Científica 44(3): 286-293.

Pinheiro JMS (2009) Tecnologia pós-colheita para a conservação de bananas da cultivar tropical. Janaúba, Dissertação de mestrado (Mestrado em Produção vegetal no Semiárido) - Universidade Estadual de Montes Claros.

Protrade (1992) Mangoes - Export manual: Tropical fruits and vegetables. Eschbom, GTZ, 1992. 34p.

Rocha LAB, Silva JC, Aninger L, Castro J, Figueiredo Neto, A (2016) Simulação computacional do resfriamento da manga Tommy Atkins. Nucleus 13(2):159165.

Safi C, Charton MC, Pignolet O, Pontalier PY, VacaGarcia C (2013) Evaluation of the protein quality of Porphyridium cruentum. Journal of Applied Phycology 25(2):497-501. 
Safi C, Zebib B, Merah O, Pontalier PY, Vaca-Garcia C (2014) Morphology, composition, production, processing and applications of Chlorella vulgaris: A review. Renewable and Sustainable Energy Reviews 35:265-278.

Santos GE, Kist BB, Carvalho CC, Reetz ER, Drum M (2014) Anuário Brasileiro da Fruticultura. Editora Gazeta Santa Cruz, Santa Cruz do Sul.

Serpa MFP, Castricini, A, Mitsobuzi GP, Martins RN, Batista MF, Almeida TH (2014) Conservação de manga com uso de fécula de mandioca preparada com extrato de cravo e canela. Revista Ceres 61(6):975-982.
Treichel M, Kist BB, Santos CE, Carvalho CC, Belinf RR (2016) Anuário Brasileiro da Fruticultura. Editora Gazeta Santa Cruz, Santa Cruz do Sul.

Trindade DCG, Lima MAC, Assis JS (2015) Ação do 1metilciclopropeno na conservação pós-colheita de manga 'Palmer' em diferentes estádios de maturação. Revista Agropecuária Brasileira 50(9):753-762.

Vieira EL, Pereira MEC, Santos DB, Lima MAC(2009) Biofilm application on the quality of 'Tommy Atkins' mango fruits. Magistra 21(3):165-170.

Yemn EW, Willis AJ (1954) The estimation of carbohydrate in plant extracts byanthrone. The Biochemical Journal 57(3):508-514. 